\title{
DOES THE CENTRALITY OF HUMAN VALUES IN THE LISBON TREATY PROMISE MORE THAN IT CAN ACTUALLY OFFER? BIOMETRICS LAW AND POLICY AS A CASE STUDY
}

Maria Eduarda Gonçalves

Maria Inês Gameiro

Agosto 2010

WP n 2010/02

DOCUMENTO DE TRABALHO

WORKI NG PAPER

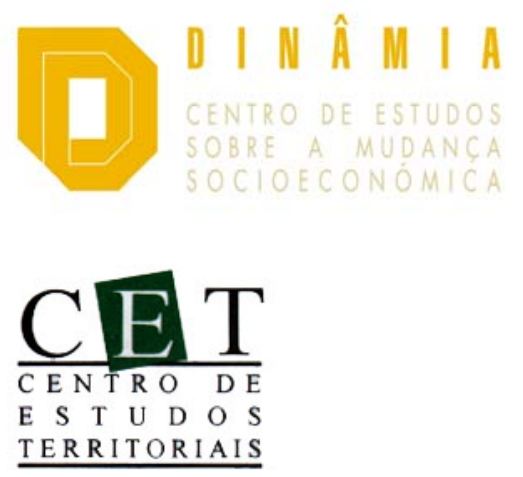

FCT 
Does the centrality of human values in the Lisbon treaty promise more than it can actually offer? Biometrics law and policy as a case study

Maria Eduarda Gonçalves*

Maria Inês Gameiro^

WP n‥ 2010/02

Agosto de 2010

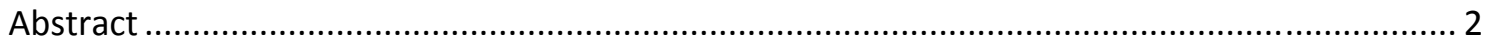

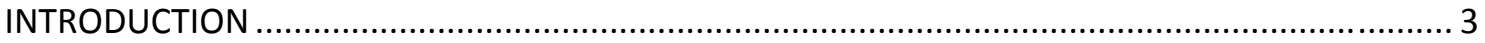

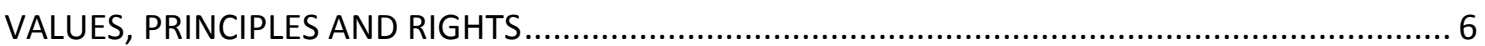

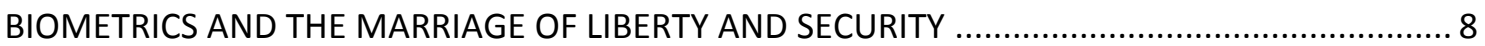

FRAMING THE BIOMETRICAL PASSPORT AS A TECHNICAL DEVICE........................................... 12

REDUCING BIOMETRICS RELATED VALUES AND RIGHTS TO BIOMETRICAL DATA PROTECTION 14 UNDERMINING THE IMPLICATIONS OF BIOMETRICS FOR HUMAN VALUES …........................... 17

COMPARING BIOMETRICS AND HUMAN CLONING LAW AND REGULATION ............................. 19

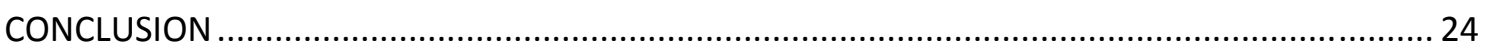

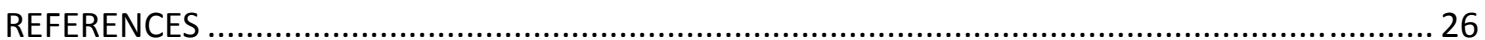

* DINAMIA/CET-IUL, Centre for Socioeconomic and Territorial Studies and ISCTE - Lisbon University Institute.

^DINAMIA/CET-IUL, Centre for Socioeconomic and Territorial Studies. 



\title{
Does the centrality of human values in the Lisbon treaty promise more than it can actually offer? Biometrics law and policy as a case study
}

\begin{abstract}
The adoption of the Treaty of Lisbon and the granting to the Charter of Fundamental Rights of the same legal force as the Treaty lent a new impulse to the consideration of fundamental human values by the European Union (EU). The question remains, however, of how this legal discourse centred on human values is actually shaping the EU regulatory framework in specific policy domains. The aim of this paper is to critically appraise the ways that certain values rendered explicit through the Charter's rights and principles are being construed in the context of EU policy and law on biometrics, an ethically and morally sensitive security technology whose development and use are being actively promoted by the EU. We conclude that the interpretation of the pertinent Charter's rights and principles as well as their balancing owes to a great deal to the goals of EU policies, shaped largely by political and economic considerations. In respect of biometrics, research priorities, combined with those of EU security policy, then tend to prevail over ethically or morally based legal claims.
\end{abstract}

Keywords: European Union; fundamental values; human rights; biometrics; security. 



\section{INTRODUCTION}

The explicit inclusion of the term 'values' is one of the originalities of the Treaty of Lisbon. Article 2 of the Treaty on European Union, consolidated by the Treaty of Lisbon, affirms that 'The Union is founded on the values of respect for human dignity, freedom, democracy, equality, the rule of law and respect for human rights.' A related novelty of the Treaty has been the granting of the same legal force as the Treaties to the Charter of Fundamental Rights of the European Union. ${ }^{1}$ The Charter indeed emerges as the main embodiment of European values consecrated by the Treaty. However, references to liberty, democracy, respect for human rights and fundamental freedoms are not new. The Treaty on European Union (Maastricht, 1992, consolidated at Nice, 2001) had embraced them as 'principles' (Article 6). Adding the epithet of values to these principles may be seen as a symbolic reinforcement of what already represented a fundamental break from the earliest Treaty of Rome, which established the European Economic Community (EEC) (1957). In fact, the goal of the EEC was primarily economic, i.e., the establishment of 'a common market and progressively approximating the economic policies of Member States' (Article 2) as well as common policies in the fields of agriculture, transport and external trade (Article 3). In that context, there was more emphasis on basic economic freedoms than on fundamental values or principles. ${ }^{2}$

There is no doubt that the Charter offers a prime setting for the expression of the most prized European values in the form of both fundamental individual and collective rights and fundamental principles. Accordingly, the Charter has been regarded as an effort to make human rights determine rather than simply limit a EU system predominantly designed to guarantee market freedoms by requiring the legislator and the judiciary to practise tilting the balance between regulatory policies and individual freedoms in favour of the latter. ${ }^{3}$ It has also been argued that a process mirroring the construction of the internal market may be in the making for fundamental human rights as well: with

\footnotetext{
${ }^{1}$ The Charter was first adopted on the $7^{\text {th }}$ of December 2000, and later adapted at Strasbourg, on the $12^{\text {th }}$ of December 2007, with no binding effect. Article 6, paragraph 1, of the Treaty states that 'The Union recognizes the rights, freedoms and principles set out in the Charter of Fundamental Rights of the European Union of 7 December 2000, as adapted at Strasbourg, on 12 December 2007, which shall have the same legal value as the Treaties.'

2 The so-called "basic economic freedoms" of the Internal Market are the free movement of workers, capital and services; free trade; and the free establishment of enterprises in EEC territory. Accordingly, for many decades priority was given to market-based objectives as particularly shown by the primacy of market freedoms in the case law of the European Court of Justice (ECJ). See S. Curzon, 'Fundamental rights and the Internal Market. The state of affairs following Schmidberger \& Omega', in J oël Rideau (dir.), Les Droits Fondamentaux dans I'Union Européenne (Bruylant, 2009), 110 and 116, acknowledging the tendency of the ECJ to subordinate fundamental rights protection 'to the protection of fundamental economic freedoms' to be related to the 'unbreakable bond which exists between the European Court of J ustice and the founding treaties which created it.' According to this author, even as it developed timidly and slowly, the protection of fundamental rights by the ECJ continued to be perceived as an exception to the general rule of the market's fundamental freedoms, cfS. Curzon, 'Fundamental rights and the Internal Market...', 122.

${ }^{3}$ A. von Bodgandy, The European Union as a Human Rights Organization? Human Rights and the core of the European Union', (2000) 37 Common Market Law Review, 1307-1338, 1321.
} 
negative rights and freedoms and positive rights and freedoms too; in other words, ' $\mathrm{a}$ comprehensive, coherent, balanced and forward-looking EU human rights policy’ ${ }^{4}$

Yet, while the adoption of the Charter has raised such optimistic expectations, the question remains in what manner European values and their embodiment into the Charter's rights and principles are shaping legislation in specific fields. Whilst the dealings of the EU judiciary with fundamental human rights have been the object of extensive scholarly analysis, limited attention has been devoted to the role of the legislative process in values' definition and balancing. How is the meaning of various constitutional values being construed through the EU law making process? And, while giving meaning to values in law and regulation, to what extent does the EU legislator show concern for the perceptions of the relevant values and rights by European citizens?

In this connection one might claim that the relevant issue facing the values and rights fabric is not just the impact of their constitutionalization, but also institutions, procedures and substantive principles that an advanced democratic system ought to ensure. Indeed, the design of the decisionmaking system, including the extent to which it provides for public consultation or public participation, may facilitate or otherwise constrain the receptiveness of the legal and regulatory system to particular values as well as shape how these are interpreted. As Foucault observed, in decision-making contexts power ultimately depends on the way the authority to decide on the relevant questions and the procedures for controlling and circumscribing the role of the various social actors are legally and institutionally regulated. ${ }^{5}$

A domain falling under EU's jurisdiction, and in which respect for the Treaty and the Charter's values is particularly critical in this day and age, is technological innovation and its effects on European society. Technological advance has been perceived as a prerequisite for improving social and economic progress since modern times. The accelerated pace of development and the employment of new technologies, in particular, biotechnologies, including genetic modification and cloning, information technologies or security technologies have created a rather uncertain picture whereby benefits tend to be more and more balanced against potential harmful impacts or risks. ${ }^{6}$ Likewise the interference of new technology with moral and ethical values regarded as fundamental by European societies for example human dignity and integrity, privacy or liberty, have become

\footnotetext{
${ }^{4}$ P. Alston, J. Weiler, 'An "ever closer union" in need of a human rights policy', in P. Alston (ed), The EU and Human Rights (Oxford University Press, 1999), 1, 8. In the EU context, human rights are most often referred to as 'fundamental rights.' No major conceptual difference is involved and the terms will be used interchangeably in this article. The distinction between fundamental (human) rights (not listed in the Treaties) and fundamental (economic) freedoms (listed in the Treaties) is relevant, however. Some consider economic freedoms to be human rights, but that is not the generally accepted view, cf von Bogdandy, The European Union as a Human Rights Organization? ...' , 1326.

${ }^{5}$ M. Foucault, The Order of Things: An Archaeology of the Human Sciences (Pantheon, 1970).

${ }^{6}$ B. Wynne et al, Taking Knowledge Society Seriously (European Commission, 2007).
} 
prominent. All find expression in the Charter of Fundamental Rights in the form of fundamental principles or principles, and thus take on a normative quality.

Against this backdrop, the present paper aims to appraise in what manner the legal and political discourse focused on human values can possibly shape the EU regulatory framework in a specific field, ie biometrics. Biometrics is a security technology whose development is being actively supported by the EU and is employed mainly for individual and collective surveillance. Biometrics elicited public controversy and anxiety across Europe that we take as an indicator of its problematic nature and of the dilemma that it raises over values such as human dignity, individual autonomy, liberty and privacy.

The paper will begin by clarifying the key relevant concepts, namely values, principles and rights and how they relate to each other. Legal principles and human rights will provide the main points of entry for our review of European values in EU law and regulation on biometrics. The EU approach to biometrics will then be compared with the EU's handling of another delicate issue, human cloning, a biotechnology presently at the exploratory stage. The ways in which the EU legislator is addressing the pertinent value dilemmas will be discussed in the light of the political and social context. One key interrogation will be whether notwithstanding its legitimating aim, the novel discourse is perhaps working at the end of the day as a substitute for democratizing the EU decisionmaking system. 


\section{VALUES, PRINCIPLES AND RIGHTS}

Broadly speaking, the law is essentially shaped by values: on a more general and abstract level, by the law's intrinsic values of justice, equality or security and, on a more practical level, by those values that are codified by the choices of the legislator in each domain of policy or regulation. The former tend toward universalization whereas the latter are evolving and changing, as they are framed by a society undergoing permanent processes of adjustment today. ${ }^{7}$ In reality, the institutions and procedures that constitute our political systems typically shape the process of translating ethically based values into the law.

Values understood as ends or ideals to be pursued, or as standards of morality or justice, enter the law through principles and rights. The EU Charter on Fundamental Rights offers a paradigmatic example of a human rights protection system that combines principles and rights, including freedoms.

It has been suggested that values may be approached in two consecutive phases: firstly, philosophical reflection on morals or ethics and; secondly, the definition of norms referring to those values and leading to rules of conduct, including legal rules. ${ }^{8}$ Principles and norms and their relation to values have been immersed in 'confusion and controversy', stated Alexy. ${ }^{9}$ While Dworkin saw principles as standards to be observed because they constitute requirements of 'justice or fairness or some other dimension of morality, ${ }^{, 10}$, Alexy defined principles as 'norms commanding that something must be realized to the highest degree that is actually and legally possible. ${ }^{11}$ For Habermas principles 'have a deontological sense', while values that are embraced by the law are teleological. ${ }^{12}$ In the end, the most obvious distinctive feature of a legal principle may possibly lie in its juridical, rather than merely ethical or social quality, which is why it must be included in a formally legal norm.

Values lead to principles, which may assert rights and then from rights into rules and regulatory instruments in a 'series of interlocking definitions and distinctions'. ${ }^{13}$ Such a 'legal cascade' flows from moral or ethical principles to ordinary law and case law. Attention should be drawn to the fact that there is no longer a rigid legal hierarchy. Different layers of principles and norms interrelate and influence one another. General principles of law, particularly those accepted by

\footnotetext{
${ }^{7}$ E. Morin, 'L'éthique de la complexité et le problème des valeurs au XXI ${ }^{\mathrm{e}}$ siècle', in Jerome Bind (dir.), Où Vont les Valeurs? (Éditions Unesco/Albin Michel, 2004), 94.

${ }^{8}$ R. Marche, 'Conflits de valeurs entre la recherche et la société', in I. de Lamberterie, É. Vergès (dir.), Quel Droit pour la Recherche? (LexisNexis, 2008), 34.

${ }^{9}$ R. Alexy, A Theory of Constitutional Rights (Oxford University Press, 2010), 45.

${ }^{10}$ R. Dworkin, Taking Rights Seriously (Duckworth, 1977), 22.

11 R. Alexy, 'Rights, Legal Reasoning and Rational Discourse', (1992) Ratio Juris, 5, 2, 143-152, 145.

12 J. Habermas, Between Facts and Norms, Contributions to a Discourse Theory of Law and Democracy (The MIT Press, 1996), 255.

${ }^{13}$ Such is the classic positivist 'fundamental test', cf R. Dworkin, Taking Rights Seriously, 18.
} 
the EU and included in the Charter of Fundamental Rights, provide an illustration of this interaction. ${ }^{14}$

Principles, conceptualised by some legal positivists as imperfect norms, provide general normative guidelines to be developed through legal norms per se. ${ }^{15}$ Thus, both principles and norms are more or less general instructions for the expected behaviour of defined groups or the expected performance of a specific activity. A deeply interrelated concept is that of rights. Rights can be construed as freedoms to act or to refrain from acting, or as entitlements to be acted upon or not acted upon that are provided by law. As societies become more complex, more and more rights, including freedoms, translate into obligations addressed to states or to third parties to ensure that their content is fulfilled. The distinction between principles and rights in the Charter can easily be realized through a simple reading. ${ }^{16}$ Article 51, paragraph 1 of the Charter, according to which EU institutions and Member States shall 'respect the rights' and 'observe the principles', while not differentiating these concepts neatly, clarifies the common responsibility of public authorities 'to promote the application' of both principles and rights. Further elucidation comes from the Explanations of the Charter: principles may be implemented through legislative or executive acts and shape the courts' interpretation or review of those acts; they contrast with rights since they do not 'give rise to direct claims for positive action by the Union's institutions or Member States authorities. ${ }^{17}$ Can one infer from this that principles are weaker in their effect? Opinions vary in this respect. While some consider them 'the poor parents' of the Charter, subject to the discretion of policy-makers $^{18}$, one may counter-argue that European institutions are compelled by the Charter to comply with principles and can even be judicially responsible for not complying with them. ${ }^{19}$

It should also be recalled that several of the principles and rights guaranteed by the Charter of Fundamental Rights are likely to collide with one another. Conflicts or clashes of rights are familiar notions in the eyes of the law. Yet, the belief that contradictory values or rights can easily be conciliated has been particularly pervasive in legal as well as political discourse.

\footnotetext{
14 P. Haberle, El Estado Constitucional (Universidad Nacional Autónoma de México, Instituto de Investigaciones Jurídicas, 2003), 127.

${ }^{15}$ G. Zagrebelsky, 'Diritto per: valori, principi o regole? (a proposito della dottrina dei principi di Ronald Dworkin)', (2002) Quaderni fiorentini per la storia del pensiero giuridico moderno, 31, 865-897, 870.

16 A. G. Soares, A Carta dos Direitos Fundamentais da União Europeia, (Coimbra Editora, 2002), 69. For exemple, Article 37 affirms the principle that "A high level of environmental protection and the improvement of the quality of the environment must be integrated into the policies of the Union and ensured in accordance with the principle of sustainable development." Article 6 proclaims the right of "everyone" to "liberty and security of person".

${ }^{17}$ European Union, Explanations relating to the Charter of Fundamental Rights, 2007/C 303/02, 35.

18 A. Kiss, 'Environmental and consumer protection', in S. Peers and A. Ward (eds.), The EU Charter of Fundamental Rights. Politics, Law and Policy (Hart Publishing, 2004), 247.

19 J. Habermas, Law and Morality, The Tanner Lectures (Harvard University, 1986).
} 
Based on this conceptual background, we will now endeavour to assess how fundamental rights and principles asserted by Charter of Fundamental Rights are being construed and balanced by the European legislator in respect of biometrics.

\section{BIOMETRICS AND THE MARRIAGE OF LIBERTY AND SECURITY}

Security (in the sense of absence of harm in the physical sense), privacy and liberty are the most obvious values challenged by biometrics. But other values may also be at stake, particularly human dignity and even democracy. As the use of biometrics grows, concerns about its bearing on civil liberties and their underlying values have been amplified. In fact, biometrics technology has become one of the central aspects of national and international security and immigration policies in Europe and is also becoming increasingly important economically as it is employed more and more to control the access of workers, students and other categories of people to various organisations. ${ }^{20}$ Similarly to other security technologies, biometrics has been a priority area for funding under the EU Framework Programme for Research and Development for over a decade. The EU has also been a major player in promoting biometrical applications, namely in passports and travel documents issued by Member States (Council Regulation (EC) No. 2252/2004 of 13 December 2004). This technology rose to the centre of techno-juridical and techno-political debates of our era particularly after ' $9 / 11$ ', when security measures were tightened worldwide, and moved closer the idea of a 'maximum security society. ${ }^{21}$

Biometrics relies on human characteristics to verify the identity of an individual. Face features, fingerprints, hand impressions, iris recognition or DNA are the kind of physiological features that can be used in biometrics. Biometrics can thus be defined as the identification of individuals using their biological or behavioural characteristics. ${ }^{22}$ When collecting biometrical data, the physical integrity of the subject should be secured against any harm, it has been argued. As well

\footnotetext{
20 Institute for Prospective Technological Studies (IPTS), 'Biometrics at the Frontiers: Assessing the Impact on Society', (2005) J oint Research Centre, European Commission, 80-87 http://ec.europa.eu/justice_home/doc_centre/freetravel/doc/biometrics_eur21585_en.pdf.

${ }^{21}$ G. T. Marx, 'La société de sécurité maximale', (1988) Déviance et Société 12, 2, 147-166. This comes from a number of EU documents such as the Proposal for a Council Regulation laying down a uniform format for visas and residence permits, $\operatorname{COM}(2003) 558$ final, and the Proposal for a Council Regulation on standards for security features and biometrics in EU citizens' passports, $\operatorname{COM}(2004) 116$ final. However, it has also been pointed out that the justification of $9 / 11$ fails partly since most terrorists travel with their own valid passports, G. Hornung, The European Regulation on Biometric Passports: Legislative Procedures, Political Interactions, Legal Framework and Technical Safeguards', (2007) SCRIPT-ed, 4, 3, 246-262, 259, http://www.law.ed.ac.uk/ahrc/script-ed/vol4-3/hornung.pdf.

22 Physiological and behavioural characteristics (voice, signature, etc.) are sometimes differentiated as biometrical indicators, but the distinction is not a peaceful one. A possible distinction is given by Article 29 Data Protection Working Party, Working document on biometrics, 10595/03/EN, WP 80, 1 August 2003, 3, http://ec.europa.eu/justice_home/fsj/privacy/docs/wpdocs/2003/wp80_en.pdf.
} 
as privacy, intimacy and the emotional integrity of the person, dignity and respect for the person's ‘decorum' also need to be considered. ${ }^{23}$ The EU Article 29 Data Protection Working Party admitted that 'collecting biometric features means collecting data of the body of a person. ${ }^{24}$ Biometrical characteristics represent a part of people's individuality and are intimately linked to the persons themselves. ${ }^{25}$ Thus the use of such new surveillance technologies results in a higher degree of complexity of value conflicts and maybe even novel value conflicts. Some authors have drawn attention to what might be a 'surveillance society' in the making, largely nurtured by unawareness of citizens themselves of the threats arising from the wide use of such technologies. ${ }^{26}$ The Article 29 Working Party acknowledged this problem for biometrical data and stressed its concern that 'the public may become desensitized ... to the effect their processing may have on daily life. ${ }^{27}$ De Hert went as far as to argue for the 'need to establish ... systems to protect individuals from their inclination to trade their own privacy. ${ }^{28}$

It is indeed feared that the current legal system may give too much leeway to new technological developments that have been initiated without proper interrogation from a human rights perspective. Within the EU, the bearing of surveillance technologies such as biometrics on fundamental human rights has been explicitly recognized. ${ }^{29}$ 'If we are not careful, we shall find ourselves headed towards a global police state, heavily manipulated by one or two strong

23 Comissão Nacional para a Protecção de Dados (CNPD), Parecer 'Princípios sobre a utilização de dados biométricos no âmbito do controlo de acessos e de assiduidade', (2004), paragraph 48, http://www.cnpd.pt/bin/orientacoes/principiosbiometricos.htm.

24 Article 29 Data Protection Working Party, Opinion on Implementing the Council Regulation (EC) No 2252/2004 of 13 December 2004 on standards for security features and biometrics in passports and travel documents issued by Member States, 1710/05/EN, WP 112, 30 September 2005, 8, http://ec. europa.eu/justice/policies/privacy/docs/wpdocs/2005/wp112_en.pdf.

${ }^{25}$ CNPD, 'Princípios sobre a utilização de dados biométricos ...', paragraph 6.

${ }^{26}$ G. T. Marx, Vigilância soft - o crescimento da voluntariedade obrigatória na recolha de dados pessoais. Ó amigo, empresta-me uma amostra de DNA?', in C. Fróís (ed.), A Sociedade Vigilante, (Imprensa da Ciências Sociais, 2008), 87-109. B. J. Goold, 'Privacy, identity and security', in B. J. Goold and L. Lazarus (eds.), Security and Human Rights (Hart Publishing, 2007), 45.

27 Article 29 Data Protection Working Party, Working Document on Biometrics, 2.

28 P. De Hert, 'Biometrics: legal issues and implications', (2005) Background paper for the Institute of Prospective Technological Studies, DG J oint Research Centre, European Commission, 38, http://cybersecurity.jrc.ec.europa.eu/docs/LIBE\% 20Biometrics\% 20March\% 2005/Legall mplications_Paul_de_He rt.pdf. Biometrics raises additional concerns such as power accumulation and the further use of existing data; the use of this technology in the private sector; and concerns about costs, cf P. De Hert, 'Biometrics: legal issues and implications', 37 and G. T. Marx, 'Vigilância soft ...'.

29 In her Opinion delivered on the Case 137/05, Advocate General Trstenjak acknowledged the problems caused by Regulation 2252/2004 from the fundamental human rights' point of view, though not developing her argument since the challenge to this regulation was not advanced by the United Kingdom on the grounds of human rights violation. See Opinion of Advocate General Trstenjak, delivered on 10 July 2007, Case 137/05, United Kingdom v Council of the European Union [2008] ERC I-11596, paragraph 126. The European Data Protection Supervisor also recognised that there can be no doubt about the importance of a strong mechanism for the protection of fundamental rights of the citizen' in the context of the EU area of freedom, security and justice, European Data Protection Supervisor, 'Opinion on the Communication from the Commission to the European Parliament and the Council on an area of freedom, security and justice serving the citizen', 2009/C 276/02, paragraph 17. 
governments. This will not make for a better world', an EC-sponsored report considered. ${ }^{30}$ In this respect, the ultimate risk for democracy of a pervasive culture of fear and the behavioural constraints that it may further through the gradual, often subtle, multiplication of security devises should not be ignored. $^{31}$

In view of these warnings, it is remarkable that the official European position on this complex matter has been based on the assumption that security and civil liberties can easily be conciliated. ${ }^{32}$ The argument has been built around the idea that biometrics can even be used to guarantee privacy (when used to restrict access to a room or a computer through a fingerprint recognition technique used by an individual person for instance) countering the idea of 'more security, less privacy' ${ }^{33}$ In a report published by the EC, it is stated that 'Privacy and data protection should not be characterised as a zero sum game where an individual gain means a societal loss or vice-versa. ${ }^{34}$ This understanding has been underlined in further policy documents reflecting the perspective of the European institutions: setting an individual value such as liberty against a more community-oriented value such as security does not necessarily mean that an individual value is being sacrificed in the name of the society - in fact, instead of a 'zero sum game', the official description points to a 'winwin' situation. Decision No. 1982/2006/EC of 18 December 2006 approving the $7^{\text {th }}$ Framework Programme on Research and Development $(R \& D)$ follows this line of reasoning when it states that 'security in Europe is a precondition of prosperity and freedom. ${ }^{35}$ This understanding is reminiscent of the theoretical approach that does not consider rights and policies to be exclusive of one another, and that the former concern the individual and the latter society ${ }^{36}$, but sees them rather as interchangeable concepts. ${ }^{37}$ In this way, European institutions could justify the role they play in biometrics and security technologies in a broader sense as one of promoting human rights.

The fact that Article 6 of the Charter of Fundamental Rights addresses liberty and security as part of the same right may appear at a first glance to support this conciliatory stance. Yet, the option

$30 \mathrm{~J}$. Ashbourn, 'The Social Implications of the Wide Scale Implementation of Biometric and Related Technologies', (2005), Background paper for the Institute of Prospective Technological Studies, DG Joint Research Centre, European Commission, 21, http://cybersecurity.jrc.ec.europa.eu/docs/LIBE\% 20Biometrics\% 20March\% 2005/Sociall mplications_Ashbourn.pdf.

31 M. Delmas-Marty, Libertés et Sûreté dans un Monde Dangereux (Seuil, 2010), 35.

32 A. Liberatore, 'Balancing Security and Democracy, and the Role of Expertise: Biometrics Politics in the European Union', (2007) European Journal on Criminal Policy and Research, 13, 109-137, 114. In fact, the search for a language of reconciliation in this area has been a pervasive stance in the European Union as elsewhere. See B. J. Goold and L. Lazarus, 'Introduction: Security and Human Rights...', 1-24.

${ }^{33}$ G. Hornung, The European Regulation on Biometric Passports ...', 249.

${ }^{34} \mathrm{~N}$. Robinson et al, Review of the European Data Protection Directive (Rand Europe, 2009), 16.

35 Dec 1982/2006/EC, Official Journal L412/26.

${ }^{36}$ R. Dworkin, Sovereign Virtue, The Theory and Practice of Equality (Harvard University Press, 2002), 23.

37 M. Atienza, J. Ruiz Manero, 'Sobre principios y reglas', (1991) Doxa: Cuadernos de Filosofía del Derecho, 10, 101-120, http://www.cervantesvirtual.com/servlet/SirveObras/12482196462352624198846/cuaderno10/doxa10_04.pdf, 106. 
for a single right was not free from controversy during the negotiations, which led to the Charter. There were proposals to separate the two concepts, and proposals to delete the reference to security, which were not successful mainly because they formed part of the phrasing of the Convention for the Protection of Human Rights and Fundamental Freedoms adopted in 1950, following a tradition of many other human rights documents. ${ }^{38}$

The 'marriage' of security and freedom can, however, be said to have changed its meaning in current times. In fact, the right to security, which was essentially understood in the past to be an allencompassing guarantee of rights, in other words, a personal security against absence of safeguards resulting on a subversion of the rule of law, is now increasingly identified with a right to protection against external threats, i.e. a physical security protection. ${ }^{39}$ Therefore, whereas in the past security came in support of freedom, it now justifies restrictions to liberties. This threat is being recognized together with the need to give precise meaning to the novel human right to security in order to counter the tendency to rendering security the 'legitimating principle upon which all fundamental rights are grounded. 40

This evolving sense of security as a right has definitely been related to the current international security policies. One might also infer from this that the latest EU option to bridge security and liberty forms part of a political strategy to render a novel EU security policy more acceptable to public opinion. This reading may help to explain the ways that the EU governing bodies are balancing the values at stake in respect of biometrics.

\footnotetext{
${ }^{38}$ Charter 4332/00, Convention 35, 160, 161, 167. It should be recalled that the Convention for the Protection of Human Rights was influenced by the historical and social background of World War II. The context of the Charter was assumedly different and in other domains it departs from the Convention, namely by including new rights and freedoms, showing that the option to maintain the same phrasing regarding the 'right to liberty and security' was neither neutral nor necessarily 'natural'.

39 M. Delmas-Marty, Libertés et Sûreté dans un Monde Dangereux, 22 ; L. Lazarus, 'Mapping the right to security', in B. J. Goold and L. Lazarus (eds.), Security and Human Rights (Hart Publishing, 2007), 333.

${ }^{40}$ L. Lazarus, 'Mapping the right to security', 328.
} 


\section{FRAMING THE BIOMETRICAL PASSPORT AS A TECHNICAL DEVICE}

The most relevant legal framework on biometrics in the EU is currently Council Regulation (EC) No. 2252/2004 of 13 December 2004 on standards for security features and biometrics in passports and travel documents issued by Member States ${ }^{41}$; and Directive 95/46/EC of the European Parliament and of the Council of 24th October 1995 on the protection of individuals with regard to the processing of personal data and on the free movement of such data, rendered applicable to personal data to be processed in the context of passports and travel documents by Regulation No. 2252/2004 (Article 4). ${ }^{42}$

It should be recalled that the introduction of the biometrical passport in the EU was a consequence of specific pressure from the government of the United States of America in the context of the 'war on terror.' Referring to the rush to using biometrics in Europe, an EC-sponsored report noted that, 'The driving force has of course been entirely political and aimed at demonstrating some sort of response to terrorism and national security, while simultaneously introducing vastly increased powers of law enforcement activity. ${ }^{43}$

Following the initiative of the European Council of Thessaloniki, in 2003, calling for a consistent approach on biometrics for documents from the nationals of third countries, EU citizens and information systems, the Commission submitted a draft regulation on standards for security features and biometrics in EU citizens' passports. This draft was discussed at the Justice and Home Affairs Council on $25^{\text {th }}$ and $26^{\text {th }}$ October 2004. The Council agreed with the proposal from the Commission, regarding the mandatory nature of fingerprints in the passport that had initially been regarded by the Council as optional. ${ }^{44}$ The Commission's proposal was subsequently discussed by the European Parliament, which introduced changes to the draft regulation. The Parliament expressed its concerns about the mandatory nature of fingerprints and the creation of a central database of EU passports and travel documents, and called for the involvement of the Article 29 Working Party. ${ }^{45}$ However, the Commission did not consider this proposal and the Council approved

\footnotetext{
${ }^{41}$ Reg 2252/2004 contemplates passports and travel documents issued by Member States. It does not apply to identity cards issued by Member States (Art 1, paragraph 3).

${ }^{42}$ Reg 390/2009 of the European Parliament and of the Council of 23 April 2009 amending the Common Consular Instructions on visas for diplomatic missions and consular posts in relation to the introduction of biometrics, including provisions on the organisation of the reception and processing of visa applications also refers to biometrics in a similar way to Reg 2252/2004.

$43 \mathrm{~J}$. Ashbourn, 'The Social Implications of the Wide Scale Implementation ...' 20.

44 Article 29 Data Protection Working Party, Opinion on Implementing the Council Regulation (EC) No 2252/2004, 4-5.

45 European Parliament legislative resolution on the Proposal for a Council Regulation on standards for security features and biometrics in EU citizens' passports,

http://www.europarl.europa.eu/sides/getDoc.do?pubRef=-//EP//TEXT+TA+P6-TA-2004-0073+0+DOC+XML+V0//EN.
} 
the Regulation eleven days later, on 13th December $2004 .{ }^{46}$ In the end, the Regulation was adopted with no extended debate and without the 'careful scrutiny' requested by the Article 29 Working Party. ${ }^{47}$

Interestingly enough, EU Regulation No. 2252/2004 is basically a technical normative text rather than a value or rights-oriented one. The Regulation focuses on the technical specifications and standards for passports and travel documents, which it seeks to harmonize across the EU. ${ }^{48}$ In a rather technocratic tone, the emphasis is put on biometrics as a requirement for the more secure and reliable identification of holders and on protection against falsification or other fraudulent use.

From the fundamental human rights point of view, the European legislator has limited its concern to biometrical data protection, thus discounting the implications of the employment of biometrics for individual privacy, including the intimacy component of privacy, as well as for freedom and democracy more generally. In truth, as pointed out, with biometrics, it is the human body that is being modelled and digitalized, and turned into an instrument under control, something that the EU initiatives have disregarded entirely.

Moreover, by providing incentives for the development of security technologies through its $R \& D$ framework programme, the EU is stimulating the expansion of an industry, and therefore a 'market' of surveillance, which may naturally share an interest in securitarian policies. The potential detrimental consequences for democracy of an expansive use of biometrics and other surveillance technologies are also played down in EU political discourse as they are rather portrayed as a means of protecting our democratic systems against external threats. Furthermore, conceiving of security and freedom as merged into one single right helps to reduce the scope for conflict about these rights, therefore to elude grounds for dispute in that connection.

However, biometrics is, we maintain, at the centre of a genuine conflict where liberty, in the sense of both the free movement of persons and individual autonomy and self-determination, is set against security as it is now understood, and involving not only strengthened border controls, but also the more general control of individual behaviour.

\footnotetext{
${ }^{46}$ Several documents evidence this tension between the main governing bodies of the EU. cf the Proposal for a Council Regulation on standards for security features and biometrics in EU citizens' passports and the European Parliament legislative resolution on the proposal for a Council regulation on standards for security features and biometrics in EU citizens' passports. cf also G. Hornung, 'The European Regulation on Biometric Passports ...', 255.

${ }^{47}$ Article 29 Data Protection Working Party, Working Document on Biometrics, 2. In this connection, let us also recall the appeal by the International Conference on Data Protection Commissioners stressing that 'the widespread use of biometrics will have a far-reaching impact on the global society and should therefore be subject to an open worldwide debate'. of the $27^{\text {th }}$ International Conference on the Data Protection Commissioners' Montreux Declaration “The protection of personal data and privacy in a globalised world: a universal right respecting diversities", http://privacy.org.nz/assets/Files/22718821.pdf.

${ }^{48}$ Art 1, Reg 2252/2004, amended by Reg 444/2009.
} 
In sum, the effects of biometrics per se as a technology involving a particularly delicate sort of personal invasiveness and the perils that it carries for the workings of democracy have not been truly questioned or debated at EU level. EU regulatory action focused on the technical standardisation of biometrical passports and travel documents, whose utility was somehow taken for granted in the political circumstances of the time. From the substantive legal standpoint, attention was drawn away towards biometrical data protection, a rather more confined and firm legal terrain. ${ }^{49}$

\section{REDUCING BIOMETRICS RELATED VALUES AND RIGHTS TO BIOMETRICAL DATA PROTECTION}

The biometrical process actually involves capturing and collecting information relating to an identified or identifiable natural person 'who can be identified, directly or indirectly, in particular by reference to an identification number or to one or more factors specific to his physical, physiological, mental, economic, cultural or social identity', according to the EU data protection directive (Directive 95/46/EC, Article 2, a). As already noted, personal data protection represents an important dimension of biometrics regulation, but one that does not fill the gap referred to above.

Directive 95/46/EC balances different policy goals, interests and rights, particularly those of public and private organisations for the use of personal data and those of the data subjects in the good use and protection of such data. The data controller must ensure compliance with a series of principles, including the principle of data quality and the principle of transparency (Article 6). These principles are echoed in Article 4, Nos. 2 and 3 of Regulation No. 2252/2004. The data subjects have the right to know who the data controller is, the purpose of the processing and the recipient of the data, and to have inaccurate data rectified (Articles 10 and 11). However, data protection legislation has shortcomings in terms of the interests of individuals, given that it allows the data processor to be the first arbiter of the need to process the data. ${ }^{50}$

The Directive contains strengthened protections for the use of special categories of personal data, particularly data relating to racial or ethnic origin, religious or philosophical beliefs, and health

\footnotetext{
${ }^{49}$ The importance of personal data protection and the widening of its scope have been acknowledged in the 'Human Rights Report' of 2010, published by the European Union Agency for Fundamental Rights, established in 2007. This report, the first since the entry into force of the Lisbon Treaty, acknowledges the relevance of the rights to the protection of personal data and to privacy, European Union Agency for Fundamental Rights (EUAFR), Annual Report, 2010, 3, http://www.fra.europa.eu/fraWebsite/attachments/AR_2010-confedition_en.pdf. This is also revealed by the 2010 budget of the FRA, which includes in the 'freedoms' operational budget a category for the information society and, particularly respect for private life and protection of personal data, and another for visa and border control, in addition to the category for asylum and immigration. Cf EUAFR, 'Statement of revenue and expenditure of the European Union Agency for Fundamental Rights for the financial year 2010', 36 and 48,

http://fra.europa.eu/fraWebsite/attachments/FRA_2010_revenue-and-expenditure_en.pdf.

${ }^{50}$ Existing data protection rules on the use of biometrics 'lack normative content and ethical debate', IPTS, 'Biometrics at the Frontiers ...' 16.
} 
and sex life (Article 8). In view of their hypersensitive nature, biometrical data may be regarded as an additional category of personal data deserving special protection. Acknowledging the growing collection of biometrics, the Article 29 Working Party considered that biometrical data should only be used in a subsidiary way, or rather, whenever 'less intrusive material' does not allow the same effect. $^{51}$ The Working Party added that when choosing biometrics 'an evaluation of the respect for proportionality and the respect for legitimacy is necessary, taking into account the risks for the protection of fundamental rights and freedoms of individuals and notably whether or not the intended purpose could be achieved in a less intrusive way. ${ }^{52}$ The French Data Protection Authority, the 'Commission nationale de l'informatique et des libertés' (CNIL), followed this line of reasoning by observing the importance of proportionality when dealing with biometrics. ${ }^{53}$ The balancing approach has been questioned, however, as it reduces rights to comparisons of relative weight, thus overlooking their fundamental moral status. ${ }^{54}$

The recognition by recent official EC reports of the lack of appropriate personal data protection in the former third pillar of the EU (ie, the area of freedom, security and justice) further reinforces the ensuing threat from the point of view of liberty and privacy. Indeed, the main limitation currently faced by the EU to provide for effective and comprehensive data protection arises from the constitutional architecture of the former EU pillars. While data protection is highly developed in the former first pillar (the internal market) of the EU, the data protection regime in the former third pillar cannot be regarded as satisfactory. Yet the former third pillar of the EU comprises areas such as police cooperation, the fight against terrorism, and matters of criminal law where the need for data protection is especially important. ${ }^{55}$

In fact, restrictions to privacy and personal data protection are accepted according to the Data Protection Directive if required to safeguard national security, defence, public security, prevention and criminal investigation, economic or financial interests of Member States or of the EU, and the rights and freedoms of others (Article 13) ${ }^{56}$ These kinds of limitations on privacy and data protection for security or defence are also provided for in Article 52, paragraph 1 of the Charter of

\footnotetext{
${ }^{51}$ Article 29 Data Protection Working Party, The Future of Privacy, Joint Contribution to the Consultation of the European Commission on the legal framework for the fundamental right to protection of personal data, 02356/09/EN, WP 168, 2009, 27.

52 Article 29 Data Protection Working Party, Working Document on Biometrics, 6.

53 CNIL, Délibération no. 2007-368 du 11 décembre 2007 portant avis sur un projet de décret en Conseil d'Etat modifiant le décret $n^{\circ} 2005-1726$ du 30 décembre 2005 relatif aux passeports électroniques, http://www.cnil.fr/en-savoir-plus/deliberations/deliberation/delib/130/\#.

54 S. Tsakyrakis, 'Proportionality: An assault on Human Rights?', (2008) Jean Monnet Working Paper 09/08, http://centers.law.nyu.edu/jeanmonnet/papers/08/080901.pdf.

55 EUAFR, Data Protection in the European Union: The Role of National Data Protection Authorities, Strengthening the fundamental rights architecture in the EUII (2010), 18, http://www.fra.europa.eu/fraWebsite/attachments/Data-protection_en.pdf

56 This provision finds its inspiration in Art 8 of the European Convention for the Protection of Human Rights and Fundamental Freedoms.
} 
Fundamental Rights, where these limitations are subject to respect for the essence of the right to protection of personal data and the requirements of necessity and proportionality.

Two critical observations may be made in this respect: firstly, in those provisions security is understood to be a public interest, not an individual right; secondly, restrictions to fundamental rights in the name of the public interest such as those referred to in Article 13 (including national and public security) should be regarded as exceptional according to general theory, and therefore interpreted restrictively. ${ }^{57}$ Configuring security as the object of an individual right equivalent to liberty, as the Charter does, may have the effect of circumventing the standard hierarchy between the values involved in individual rights and the public interest, thereby consenting to new kinds of restrictions to fundamental rights (liberties, privacy, etc.) in the name of the also fundamental 'right to security'. In this way, reducing biometrics regulation to data protection law may add to limiting the scope for taking the human values at stake into due consideration. In the light of current EU policy and law on biometrics, the expectation expressed in the following excerpt of a recent European Union Agency for Fundamental Rights (EUAFR) report may appear too optimistic:

Article 8 of the Charter on the protection of personal data will be in a position to play a role, which goes far beyond its formal and symbolic proclamation as a fundamental right. The recognition of data protection as an autonomous fundamental right with full legal validity as part of primary EU law means that data protection will play a more important role when balanced with other values and interests (eg security or market interests), and when priorities are being defined by the EU legislator and by the EC. ${ }^{58}$

57 'When confronted with national security issues what is called for is a proportionality test, ie balancing fundamental rights against other interests and not simply overriding the former', EUAFR, Data Protection in the European Union ..., 46.

${ }^{58}$ EUAFR, Data Protection in the European Union..., 18. 


\section{UNDERMINING THE IMPLICATIONS OF BIOMETRICS FOR HUMAN VALUES}

One may legitimately deduce from the above that, all in all, the European urge for the development and use of biometrics overestimates the values of security and of the internal market (to the extent that it promotes a surveillance industry) without due regard to their impact on individual freedoms and democracy. Actually, biometrics as a security or surveillance technology has not been officially questioned for its potential risk to human rights or other fundamental EU values even at a time when a Charter of Fundamental Rights has been formally adopted. Concerns expressed by a number of observers, including in reports drawn up for the European Commission on the potential interference of biometrics with human rights (freedom, privacy and intimacy and ultimately human dignity), and more generally with the workings of democratic society, have been somewhat overlooked. Quite the contrary, biometrics has been regarded a legitimate and even desirable technological innovation as is apparent from the EU's active promotion of security technologies.

The introduction of biometrics in passports and travel documents in the EU was, as said before, a consequence of a political decision made under pressure from the USA. Once that political decision had been made, the EU pursued its conventional and somewhat instrumental path towards the harmonisation of technical standards. Human rights considerations were formatted chiefly as a personal data protection issue resembling other data digital applications to be addressed under the existing general data protection regime, thus neglecting the special sensitivity of biometrical data in terms of privacy and intimacy, and ultimately human dignity. The prospects opened up by the Treaty of Lisbon's novel emphasis on values, and by the Charter, for the renewed and greater responsibility of EU institutions to 'promote the application' of fundamental human rights in the light of scientific and technological developments have been fairly discouraged, at least for now. The reading of this conclusion should bear in mind the conceptual ambiguity and the evolution of the significance of the values, principles and rights proclaimed by the Treaty and the Charter, as well as the contexts in which they are interpreted and applied. In fact, in the face of the newly perceived threats from terrorism and criminality, the upgrading of security to the status of a human right which is equal to the right to liberty represents a change from the traditional understanding of public security as a general interest which is likely to work against the rights of the individual and, therefore, to be interpreted in a restrictive manner.

We believe that the ensuing conceptual variation provides a powerful illustration of the different ways that the meaning of principles and rights laid down in the Treaty and the Charter can be construed and balanced in the light of specific European policies and strategies. In view of their general nature, their real sense is only defined or redefined thoroughly through implementation in certain fields and points in time. In reality, the EU legal framework for biometrics is being shaped by 
current policies on internal and external security policies and raises legitimate doubts about the suitability of the resulting balancing of rights to the new centrality of human values in the EU constitutional framework.

Furthermore, the acceptance of biometrics appears to have bypassed the appropriate procedural arrangements that might have made it more in line with the promises of a European values-based law and regulation, more responsive to European citizens' concerns and aspirations, opened up by Treaty and the Charter. As claimed by the IPTS in its 2005 report on biometrics,

It is time also to bring citizens squarely into the debate. Not by carefully manipulated opinion polls, but by honest and open public discussion. .... The dialogue to date has been heavily influenced by commercial interest and political aspirations. There has been remarkably little genuine consultation with citizens on a matter, which will have a significant impact upon society. $^{59}$

The 'security exception' is continuing to provoke the latest developments in EU policy. In March 2010, the European Commission presented a 'Proposal of a Regulation for the creation of an Agency for the operational management of large-scale IT systems in the area of freedom, security and justice' covering matters related to checks on persons at external borders, illegal immigration and illegal residence and asylum. ${ }^{60}$ Here again, the European Parliament expressed reservations about its possible threat for human rights. ${ }^{61}$

${ }^{59} \mathrm{~J}$. Ashbourn, 'The Social Implications of the Wide Scale Implementation ...', 21.

60 European Commission, 'Proposal of a Regulation for the creation of an Agency for the operational management of large-scale IT systems in the area of freedom, security and justice', COM (2010) 93 final, http://eur-lex.europa.eu/LexUriServ/LexUriServ.do?uri=COM:2010:0093:FIN:EN:PDF.

61 European Parliament, Draft Report on the amended proposal for a regulation (of the European Parliament and of the Council establishing an Agency for the operational management of large scale IT systems in the area of freedom, security and justice, (COM(2010)0093 - C7-0046/2009 2009/0089(COD)), http://www.europarl.europa.eu/sides/getDoc. do?pubRef=//EP//NONSGML+COMPARL+PE440.994+01+D $\mathrm{OC}+\mathrm{PDF}+\mathrm{V} 0 / / \mathrm{EN} \&$ language $=\mathrm{EN}$.

The European Parliament's draft report states that 'The rapporteur has amended a number of articles in an attempt to strengthen Parliament's role and enhance transparency. He has likewise sought to tighten up the rules on data protection and the integrity and of personal data by strengthening the role of the European Data Protection Supervisor.', European Parliament, Draft Report..., 31. 


\section{COMPARING BIOMETRICS AND HUMAN CLONING LAW AND REGULATION}

Comparison of the EU approach to biometrics and to other novel technologies with ethical implications may help to shed additional light on the EU's practical dealings with the fundamental values affirmed by the Treaty and the Charter. In this section, we attempt to compare the approaches to biometrics and cloning, particularly human cloning.

At the outset, it may be recalled that in contrast with biometrics, accepted as a legitimate technological innovation, human cloning for reproductive purposes is explicitly banned by the Charter of Fundamental Rights (Article 3, No. 2, d). Human cloning had been addressed through a European Parliament resolution by the time the Charter was first adopted. Recognising that 'the undoubted need for medical research resulting from advances in knowledge of human genetics must be balanced against strict ethical and social constraints', the European Parliament resolution on human cloning, approved in 2000, went as far as to proclaim that 'there should be a universal and specific ban at the level of the United Nations on the cloning of human beings at all stages of formation and development. ${ }^{, 62}$ 'There is no difference between cloning for therapeutic purposes and cloning for the purposes of reproduction', the Parliament believed. ${ }^{63}$ To justify this ban, the Parliament emphasised the value of 'human dignity and the consequent value of each human being., ${ }^{64}$

A difference therefore becomes apparent between the stance of the European Parliament resolution prohibiting cloning in all of its forms, and that of the Charter prohibiting reproductive cloning only, as part of the right to the integrity of the human person. ${ }^{65}$

Cloning remains one of the most controversial issues in the bioethics debate today, a debate that is far from over. ${ }^{66}$ 'Cloning is the process of producing genetically identical organisms. It may involve division of a single embryo by prompting a fertilised egg to split in two, in which case both the nuclear genes and the small number of mitochondrial genes would be "identical", or it may

\footnotetext{
62 European Parliament Resolution on Human Cloning, paragraph 10. This was also the position of the Council of Europe's 'Additional Protocol to the Convention for the Protection of Human Rights and Dignity of the Human Being with regard to the Application of Biology and Medicine, and the Prohibition of Cloning Human Beings' signed on 12 J anuary 1998, Art 1.

63 European Parliament Resolution on Human Cloning, paragraph $\mathrm{H}$.

64 European Parliament Resolution on Human Cloning, paragraph A.

${ }^{65}$ Controversy on this matter also pervades the positions of Member States. Whereas some countries oppose reproductive cloning while accepting therapeutic cloning (eg Belgium and the United Kingdom), others ban cloning altogether (eg Germany and Ireland), and still others do not have a clear position or legislation on this matter (eg Hungary and Poland) (data from 2007). K. Matthews, Overview of World Human Cloning Policies, 2007, http://cnx.org/content/m14834/latest/. For a comprehensive overview of the legal situation of cloning in the Member States in 2003, cf the Commission Staff Working Paper, Report on Human Embryonic Stem Cell Research, SEC (2003) 441.

66 Over the past 15 years, around 15 written questions regarding human cloning have been presented by members of the European Parliament, a number larger than questions about stem cell research, an apparently more controversial topic in the public sphere.
} 
involve nuclear transfer, in which case only the nuclear genes would be "identical", ${ }^{67}$ This distinction is relevant for considering the implications of cloning, particularly human cloning. ${ }^{68}$ While reproductive cloning is intended for the creation of new human lives, therapeutic cloning (non-reproductive cloning) is only for the creation of new tissues and organs from human stem cells and does not result in the creation of a new human being.

Advice by the European Commission's Group of Advisers on the Ethical Implications of Biotechnology of the European Union (GAEIB) converged with the Charter's option. The GAEIB accepted that research on nuclear transfer could have important therapeutic applications for the development of appropriate stem cell cultures for the repair of human organs. It could also provide insights into how to induce the regeneration of damaged human tissues. ${ }^{69}$ The GAEIB also showed tolerance toward non-therapeutic research on human embryos involving nuclear substitution, as long as it was conducted under strict licence, and only with 'the objective either to throw light on the cause of human disease or to contribute to the alleviation of suffering. ${ }^{70}$

In contrast, for the European Parliament, reproductive and therapeutic cloning should both be banned since any relaxation 'will lead to pressure for further developments in embryo production and usage. ${ }^{71}$ Cloning involving the creation of human embryos for research purposes poses a 'profound ethical dilemma' and 'irreversibly crosses a boundary in research norms. ${ }^{72}$

The divergence in the position of EU institutions in this domain evidences the imprecision of the right to human integrity and, more than that, of the principle of human dignity and the

${ }^{67}$ GAEIB, Ethical Aspects of Cloning Techniques, 28 May 1997,2,

http://ec.europa.eu/european_group_ethics/docs/opiniong_en. pdf.

${ }^{68}$ GAEIB, Ethical Aspects of Cloning Techniques, 4. The first method is the simplest way to create a clone. This is a technique already employed for stock breeding that together with somatic cell nuclear transfer are the main techniques of reproductive cloning, or put simply, the use of technology to create a living copy of an existing human being. The second method, cloning by nuclear replacement, or therapeutic cloning, is a technology whereby embryonic stem cells can be harvested for curing diseases and eventually to replace organs and tissues.

${ }^{69}$ GAEIB, Ethical Aspects of Cloning Techniques, 5.

${ }^{70}$ GAEIB, Ethical Aspects of Cloning Techniques, 6 . In the same vein, Dir 98/44/EC of 6 July 1998 on the legal protection of biotechnological inventions prohibits the granting of patents on processes for cloning human beings and uses of human embryos for industrial or commercial purpose (paragraphs 41 and 42) as contrary to the purposes of public order and morality (Art 5, No 1 and 6). However, such exclusion did not affect 'inventions for therapeutic or diagnostic purposes which are applied to the human embryo and are useful to it' (paragraph 42 and Art 6, No 2).

${ }^{71}$ European Parliament Resolution on Human Cloning, paragraph $\mathrm{H}$.

72 European Parliament Resolution on Human Cloning, paragraph 2 and paragraph E. This was in line with trends in EU research and development policy. of Dec 1982/2006/EC, of 18 December 2006, $7^{\text {th }}$ framework programme, Art 6 ('Ethical principles'), paragraph 2: The following fields of research shall not be financed under this Framework Programme: research activity aiming at human cloning for reproductive purposes'; Dec $1513 / 2002 / E C$, of 27 June 2002, $6^{\text {th }}$ Framework Programme, underlining that fundamental ethical principles shall be respected, including the principles highlighted in the Charter of Fundamental Rights and in the Council of Europe Convention on Human Rights and Biomedicine (Oviedo, 1997) and the Additional Protocol on the Prohibition of Cloning Human Beings (Paris, 1998) (Annex I); and Council Dec 2002/834/EC, of 30 September 2002, 'The following fields of research shall not be financed under this programme: research activity aiming at human cloning for reproductive purposes' (Annex I). 
consequent passing on of their practical definition to EU institutions which show different degrees of sensitivity to the ethical values at stake. ${ }^{73}$. Arguments based on human dignity used to reject reproductive cloning commonly differentiate matters of autonomy (the uniqueness of each human being), instrumentalism (the idea that human beings should always be treated as ends, not as means), replication (condemning replication as opposed to reproduction) and community or communal dignity, making the human genome a symbolic part of the heritage of humankind. ${ }^{74}$ Additional arguments include: security (genetic research can pose a great danger), social justice (the costs of the technology would make it only affordable for the very rich) and aesthetics (there would be less variety in the world since everyone would want to have more or less the same desired characteristics). ${ }^{75}$ Some of these arguments may also apply to therapeutic cloning from the European Parliament's viewpoint. However, some may not, particularly: the visceral public reaction to the idea of human reproductive cloning and its adverse impact on the social definition of the family and infringement of the values of human integrity and dignity. The scope of these notions and the corresponding principles indeed are far from univocal. ${ }^{76}$

A look at the negotiating process in the Convention that drew up the Charter of Fundamental Rights helps to explain the inherent conflicts of the interpretation of the values at stake. The Convention favoured an absolute prohibition of human cloning at an initial stage of its preparatory work. ${ }^{77}$ The specification of reproductive human cloning was introduced during the negotiating process. ${ }^{78}$ The preparatory draft of the Charter presented for the consideration of the Convention proposed two options, one stating that 'everyone shall have the right to the respect of his ... genetic integrity' and another adding that 'the cloning of human beings is forbidden. ${ }^{79}$ The latter eventually made its way into the Charter, while the reference to 'genetic' was removed on the grounds that it could create confusion. ${ }^{80}$ This formula was not approved without criticism. Concerns were voiced about the lack of definition of what kind of cloning would be permitted or excluded from the

\footnotetext{
73 Recent news about the discussion in the EU of novel food (meat and milk) produced through animal cloning confirms the opposing views of the Parliament and the Council: whereas the Parliament rejected their commercialisation, the Council of Ministers of Agriculture favoured the assignment of the statute of novel food to such products. of 'Des aliments issues du clonage dans l'assiette anglaise', Le Monde, 7 August 2010, 4.

74 As stated in the UNESCO Universal Declaration on the Human Genome and Human Rights, 1997, Art 1.

${ }^{75}$ R. Dworkin, Sovereing Virtue, 439.

76 T. Caulfield, 'Human cloning laws, human dignity and the poverty of the policy making dialogue', (2003) BMC Medical Ethics, 4, 2, http://www. biomedcentral.com/content/pdf/1472-6939-4-3.pdf2003.

${ }^{77}$ CHARTE 4135/00, Convent 7 and CHARTE 4149/00, Convent 13.

78 Charte4371/00, Convent 38, 4 the wording 'reproductive cloning' already appears replacing previous phrasings in some of the preparatory documents that made reference to 'cloning'.

${ }^{79}$ CHARTE 4123/1/00, Convent 5, 2-3.

${ }^{80}$ CHARTE 4135/00, Convent 7, 3, following a proposal from France.
} 
'reproductive cloning of human beings. ${ }^{, 81}$ The difficulty of reaching a consensus on the matter was recognised by the European Group on Ethics in Science and New Technologies (EGE), itself divided on the issue of cloning. ${ }^{82}$ The Explanations to the Charter clarified that in prohibiting human cloning for reproductive purposes, the Charter does not depart from the principle adopted by the Council of Europe, 'it neither authorises nor prohibits other forms of cloning. Thus it does not in any way prevent the legislature from prohibiting other forms of cloning. ${ }^{, 83}$ Several documents remark that the list in paragraph 2 of Article 3 is not exhaustive, leaving 'open the possibility of taking account of any progress in this area. ${ }^{84}$

Some of the difficulties raised by human cloning go deeper, to the point of defining human identity and the very concept of man in all of his personal and social dimensions. ${ }^{85}$ That 'human dignity is inviolable' is affirmed by the EU Charter of Fundamental Rights (Article 1). But the Charter does not provide a clear idea of the scope of this principle. Moreover, the real meaning of the principle/right dichotomy in this respect is open to discussion. The EGE admits that 'dignity, although a strong juridical and ethical concept in Europe, is a delicate idea when transposed into legal language. ${ }^{, 86}$ The Charter does not clarify these doubts, although the preparatory Convention discussed the need to recognise human dignity extensively in the first article of the Charter, as 'not only a fundamental right in itself but the real basis of fundamental rights. ${ }^{87}$ However, the lack of a careful policy analysis of the role of human dignity 'trivializes the potential value of human dignity as a normative principle', and makes it almost impossible to criticise the actual justifications behind many of the proposed policies including policies on cloning. ${ }^{88}$

The ECJ dealt with the issue of human dignity in Case 377/98 in which the Netherlands challenged the European Commission on the protection of biotechnological inventions by patents. The Netherlands, supported by other Member States, argued that Directive 98/44/EC, which allows the patenting of parts of the human body, undermined human dignity. The Court did not address the concept of human dignity in spite of using the term profusely, and decided to reject the case of the Netherlands. ${ }^{89}$ Nevertheless, a statement proffered in the same case by Advocate General Jacobs,

\footnotetext{
${ }^{81}$ CHARTE 4332/00, Convent 35, 85. The difficulties associated with definitions and interpretations of the terms 'reproductive cloning' and others were also highlighted by the British Medical Association, CHARTE 4497/00, Contrib 347, 2-3.

82 CHARTE 4370/00, Contrib 233, 19-20.

83 Explanations relating to the Charter of Fundamental Rights, Article 3.

${ }^{84}$ CHARTE 4371/00, Convent 38, 5, CHARTE 4332/00, Convent 35, 82.

85 B. Feuillet-Le Mintier, 'Un exemple de prohibition: la recherche sur le clonage humain', in I. de Lamberterie, É. Vergès (dir.), Quel Droit Pour La Recherche ?, (LexisNexis, 2006), 121.

${ }^{86}$ CHARTE 4370/00, Contrib 233, 11.

${ }^{87}$ Charte 4471/00, Convent 48, 3

88 T. Caulfield, 'Human cloning laws ...', 2.

${ }^{89}$ Case 377/98, Kingdom of the Netherlands v European Parliament and Council of the European Union, [2001] ECR I-07079, paragraphs 69-81.
} 
that 'the human body is the vehicle for human dignity', provided some clarification of the concept of human dignity, with relevance for addressing the value implications of both human cloning and biometrics. ${ }^{90}$ Actually, as noted above, biometrics also impinges on the human body, given that it involves the collection and digitalisation of images of intimate parts of the human body. Nevertheless, the principle of human dignity has not been addressed in EU law and regulation in relation to biometrics.

Thus human cloning, as a technology that interferes with human integrity and even human identity or uniqueness, appears to motivate a greater protection of human rights at EU level than biometrics, a surveillance technology, which, though affecting people's freedom and individuality, has been officially portrayed as a condition rather than a danger for liberty. It can be deduced that the ethical implications of human body manipulation, particularly when human life is at stake, raise higher levels of collective emotion and concern than matters relating to individual freedom and democracy.

It is, however, hard to establish any kind of hierarchy of these fundamental values in theory and besides, no effective inquiry or debate has been held in the public domain on the perception of these values or rights by society. In the end, the banning of human cloning was confined explicitly to its reproductive applications, despite the apprehension of the European Parliament, based on the prevailing interests of EU R\&D policy combined with a rather narrow understanding of both the ethical problems raised by therapeutic uses of cloning and the scope of the principles of human integrity and dignity.

\footnotetext{
${ }^{90}$ Opinion of Advocate General Jacobs, delivered on 14 J une 2001, Case 377/98, Kingdom of the Netherlands v European Parliament and Council of the European Union, [2001] ECR I-07079, paragraph 190.
} 


\section{CONCLUSION}

Is it reasonable to conclude that the new centrality of human values and fundamental human rights in the Treaty and the Charter promises more than it can actually offer?

The various assessments of the value implications of biometrics and human cloning in academic and non-academic appraisals and the divergent, sometimes conflicting, positions of different EU institutions and advisory bodies indicate that political and policy options offer better measures for giving practical substance to the principles and rights detailed in the Treaty or in the Charter than any ethically-based or abstract juridical interpretation of those principles or rights. In reality, the ways in which the relevant principles and rights are being defined and balanced owes appreciably to the ways that the EU is pursuing its political and policy goals.

Moreover, principles and rights, typically formulated in general terms, are open to various and evolving interpretations shaped largely by political or economic circumstances, including the impacts of technological advance. This has been particularly true for the right to security. The changing meaning of this concept in the context of the 'war on terror' entailed a redefinition of the scope of the right to freedom (in particular, to freedom of movement) as well as of the right to privacy and intimacy. The redefinition of the sense of freedom and the portrayal of security and freedom as the two sides of a single right facilitated the introduction and even the promotion of security technologies like biometrics.

The meanings assigned to the principles and rights guaranteed by the Treaty and the Charter and their translation into European regulation were to be embedded in political debate and battles between sometimes contradictory arguments within the EU system itself. In these struggles, economic and security considerations have normally prevailed over ethically or morally based legal claims, such as those based on the right to freedom or on democracy. In the regulation of biometrics, the focus on data protection (a matter already framed under established European law, i.e. Directive 95/46/EC) in detriment to the values and rights of privacy and intimacy was evidence of the EU strategy to confine sensitive issues to more easily manageable legal frameworks.

In the case of human cloning, the way chosen by the drafters of the Charter of Fundamental Rights to overcome the controversy on whether to ban human cloning absolutely or only for reproduction, by leaving it somewhat ambiguous, appears to have been designed to respond to the public outcry about the cloning of human beings, while not raising insurmountable obstacles to stem research and potential therapeutic applications of cloning.

All in all, the internal EU debates on the legal frameworks for biometrics and human cloning do not seem to have shed enough light on the practical effects of the Charter's approach to particular values as principles or as rights. Indeed, in addressing the issue of human values, the normative 
implications of a principle, including the responsibilities they involve for the EU and for the Member States (for example, the principle that human dignity is inviolable), may converge with the entitlements assigned to individuals as rights. Particularly in highly technical and organised domains such as those addressed in this paper (security technologies, biotechnologies), human rights can hardly be mobilised by individual citizens as calls for positive action by public institutions. The effective protection and promotion of human rights thus depends greatly on political and policy initiatives; in other words, on the extent to which acts by the legislative or the executive, and the interpretation or review of those acts by the courts, address the values at stake in ways that meet people’s legitimate expectations.

In this respect, it should be recalled that the EU legal and political system has not developed effective channels for stakeholders and civil society to have a say in the regulation of technological innovations and, in that way, to convey their views on the benefits and risks involved as well as morally-based considerations. In fact, warnings about the potential repercussions of biometrics on freedom, as well as on human integrity and dignity and its ensuing potential threats for democracy, voiced by expert-based reports and in public debate have been undermined due to the priority given by the EU decision-making authorities to the objectives of European security, and industrial and research policies. A similar assessment may be advanced with respect to the ethical implications of non-reproductive or therapeutic cloning.

From this it may be inferred that, despite their upgrading to a constitutional-like status, fundamental values and rights may not easily reach prominence as ends to be pursued by active policy by EU institutions. More than discourse, perhaps what is required is a new human rights culture. 'A strong human rights culture', Falk underscored, is 'the necessary underpinning of an effective regime of human rights. Such a culture cannot take hold unless the political culture is supportive of human rights. ${ }^{91}$

${ }^{91}$ R. Falk, Human Rights Horizons: The Pursuit of Justice in a Globalizing World (Routledge, 2000), 10. 


\section{REFERENCES}

$27^{\text {th }}$ International Conference on the Data Protection Commissioners' Montreux Declaration “The protection of personal data and privacy in a globalised world: a universal right respecting diversities”, http://privacy.org.nz/assets/Files/22718821.pdf

ALEXY, Robert (2010), A Theory of Constitutional Rights. Oxford: Oxford University Press.

ALEXY, Robert (1992), 'Rights, Legal Reasoning and Rational Discourse', Ratio Juris, vol. 5, n. 2, pp. 143-152.

ALSTON, P. and Weiler (1999), “An 'ever closer union' in need of a human rights policy”, in Alston, P. (ed.), The EU and Human Rights. Oxford: Oxford University Press.

Article 29 Data Protection Working Party (2003), 'Working document on biometrics', 10595/03/EN, WP 80, 1 August 2003, 3, http://ec.europa.eu/justice home/fsj/privacy/docs/wpdocs/2003/wp80_en.pdf.

Article 29 Data Protection Working Party (2005), 'Opinion on Implementing the Council Regulation (EC) No 2252/2004 of 13 December 2004 on standards for security features and biometrics in passports and travel documents issued by Member States', 1710/05/EN-rev, WP 112, adopted on 30 September 2005, http://ec.europa.eu/justice/policies/privacy/docs/wpdocs/2005/wp112_en.pdf.

Article 29 Data Protection Working Party (2009), 'The Future of Privacy, Joint contribution to the Consultation of the European Commission on the legal framework for the fundamental right to protection of personal data', 02356/09/EN, WP 168, adopted on 1 December 2009, http://ec.europa.eu/justice/policies/privacy/docs/wpdocs/2009/wp168_en.pdf.

ASHBOURN, Julian (2005), 'The Social Implications of the Wide Scale Implementation of Biometric and Related Technologies', Background paper for the Institute of Prospective Technological Studies, DG Joint Research Centre, European Commission, http://cybersecurity.jrc.ec.europa.eu/docs/LIBE\%20Biometrics\%20March\%2005/SocialImplications_Ashbourn.pdf

ATIENZA, Manuel; Juan Ruiz Manero (1991), 'Sobre principios y reglas', in Doxa: Cuadernos de Filosofía del Derecho, 10, pp. 101-120, http://www.cervantesvirtual.com/servlet/SirveObras/12482196462352624198846/cuaderno10/doxa10_04.pdf. 
Caulfield, Timothy (2003), 'Human cloning laws, human dignity and the poverty of the policy making dialogue', BMC Medical Ethics, 4, 2, http://www.biomedcentral.com/content/pdf/1472-6939-4-3.pdf.

Comissão Nacional para a Protecção de Dados (2004), Parecer 'Princípios sobre a utilização de dados biométricos no âmbito do controlo de acessos e de assiduidade’, http://www.cnpd.pt/bin/orientacoes/principiosbiometricos.htm.

Commission nationale de l’informatique et des libertés (CNIL) (2007), 'Délibération n²007-368 du 11 décembre 2007 portant avis sur un projet de décret en Conseil d'Etat modifiant le décret $n^{\circ} 2005$ 1726 du 30 décembre 2005 relatif aux passeports électroniques', http://www.cnil.fr/en-savoirplus/deliberations/deliberation/delib/130/\#.

Council of Europe (1950), Convention for the Protection of Human Rights and Fundamental Freedoms, Rome.

Council of Europe (1997), Convention on Human Rights and Biomedicine, Oviedo.

Council of Europe (1998), Additional Protocol to the Convention for the Protection of Human Rights and Dignity of the Human Being with regard to the Application of Biology and Medicine and the Prohibition of Cloning Human Beings, Paris.

Council Decision No. 2002/834/EC of 30 September 2002 adopting a specific programme for research, technological development and demonstration, "Integrating and strengthening the European Research Area" (2002-2006).

Council Regulation (EC) No. 2252/2004 of 13 December 2004 on standards for security features and biometrics in passports and travel documents issued by Member States (amended by Regulation (EC) No. 444/2009 of 28 May 2009).

CURZON, Stephen (2009), 'Fundamental rights and the Internal Market. The state of affairs following Schmidberger \& Omega', in Joël Rideau (dir.), Les droits fondamentaux dans l'Union européenne. Bruxelles: Bruylant, pp. 109-129. 
Decision No. 1982/2006/EC of the European Parliament and of the Council of 18 December 2006 concerning the $7^{\text {th }}$ Framework Programme of the European Community for research, technological development and demonstration activities (2007-2013).

Decision No. 1513/2002/EC of the European Parliament and of the Council of of 27 June 2002 concerning the $6^{\text {th }}$ Framework Programme of the European Community for research, technological development and demonstration activities, contributing to the creation of the European Research Area and to innovation (2002-2006).

DELMAS-MARTY, Mireille (2010), Libertés et Sûreté dans un Monde Dangereux. Paris: Seuil.

'Des aliments issues du clonage dans l’assiette anglaise’, Le Monde, 7 August 2010.

Directive 98/44/EC of the European Parliament and of the Council of 6 July 1998 on the legal protection of biotechnological inventions.

Directive 95/46/EC of the European Parliament and of the Council of 24 October 1995 on the protection of individuals with regard to the processing of personal data and on the free movement of such data.

Draft Charter of Fundamental Rights of the European Union, CHARTE 4123/1/00, Convent 5, 15 February 2000, http://www.europarl.europa.eu/charter/activities/docs/pdf/convent05 en.pdf.

Draft Charter of Fundamental Rights of the European Union, CHARTE 4135/00, Convent 7, 21 February 2000, http://register.consilium.europa.eu/pdf/en/00/st04/st04135.en00.pdf.

Draft Charter of Fundamental Rights of the European Union, CHARTE 4149/00, Convent 13, 8 March 2000, http://register.consilium.europa.eu/pdf/en/00/st04/st04149.en00.pdf.

Draft Charter of Fundamental Rights of the European Union, CHARTE 4332/00, Convent 35, 25 May 2000, http://register.consilium.europa.eu/pdf/en/00/st04/st04332.en00.pdf.

Draft Charter of Fundamental Rights of the European Union, CHARTE 4370/00, Contrib 233, 15 June 2000, http://www.europarl.europa.eu/charter/civil/pdf/con233_en.pdf. 
Draft Charter of Fundamental Rights of the European Union, CHARTE 4371/00, Convent 38, 15 June 2000, http://register.consilium.europa.eu/pdf/en/00/st04/st04371.en00.pdf.

Draft Charter of Fundamental Rights of the European Union, Charte 4471/00, Convent 48, 20 September 2000, http://register.consilium.europa.eu/pdf/en/00/st04/st04471.en00.pdf.

Draft Charter of Fundamental Rights of the European Union, CHARTE 4497/00, Contrib 347, 3 October 2000.

DWORKIN, Ronald (2002), Sovereign Virtue, The Theory and Practice of Equality. Cambridge: Harvard University Press.

DWORKIN, Ronald (1977), Taking Rights Seriously. London: Duckworth.

European Commission (2003), 'Report on Human Embryonic Stem Cell Research', Commission Staff Working Paper SEC (2003) 441.

European Commission (2003), 'Proposal for a Council Regulation laying down a uniform format for visas and residence permits', COM (2003) 558 final.

European Commission (2004), 'Proposal for a Council Regulation on standards for security features and biometrics in EU citizens’ passports’, COM (2004) 116 final.

European Commission (2010), 'Proposal of a Regulation for the creation of an Agency for the operational management of large-scale IT systems in the area of freedom, security and justice', COM (2010) 93 final.

European Data Protection Supervisor (2009), 'Opinion on the Communication from the Commission to the European Parliament and the Council on an area of freedom, security and justice serving the citizen’, 2009/C 276/02, http://eur-lex.europa.eu/LexUriServ/LexUriServ.do?uri=OJ:C:2009:276:0008:0020:EN:PDF.

European Parliament (2000), Resolution on human cloning, 7 September 2000, http://www.europarl.europa.eu/omk/omnsapir.so/pv2?PRG=CALDOC\&TPV=PROV\&FILE=000907\&TXTLST=1\&POS= $1 \&$ SDOCTA=8\&Type_Doc=FIRST\&LANGUE=EN. 
European Parliament (2005), 'Resolution on the proposal for a Council regulation on standards for security features and biometrics in EU citizens' passports', http://www.europarl.europa.eu/sides/getDoc.do?pubRef=-//EP//TEXT+TA+P6-TA-2004-0073+0+DOC+XML+V0//EN.

European Parliament (2010), 'Draft Report on the amended Proposal for a Regulation of the European Parliament and of the Council establishing an Agency for the operational management of large scale IT systems in the area of freedom, security and justice', http://www.europarl.europa.eu/sides/getDoc.do?pubRef=//EP//NONSGML+COMPARL+PE440.994+01+DOC+PDF+V0//EN\&language $=\mathrm{EN}$.

European Union (2007), Charter of Fundamental Rights of the European Union, 2007/C 303/01.

European Union (2007), Explanations relating to the Charter of Fundamental Rights, 2007/C $303 / 02$.

European Union Agency for Fundamental Rights - FRA (2010), 'Annual Report', http://www.fra.europa.eu/fraWebsite/attachments/AR_2010-conf-edition_en.pdf.

European Union Agency for Fundamental Rights - FRA (2010), 'Data Protection in the European Union: The Role of National Data Protection Authorities, Strengthening the fundamental rights architecture in the EU II', http://fra.europa.eu/fraWebsite/attachments/Data-protection en.pdf.

European Union Agency for Fundamental Rights - FRA (2010), 'Statement of revenue and expenditure of the European Union Agency for Fundamental Rights for the financial year 2010', http://fra.europa.eu/fraWebsite/attachments/FRA_2010_revenue-and-expenditure_en.pdf.

FALK, Richard (2000), Human Rights Horizons: The Pursuit of Justice in a Globalizing World. London: Routledge.

FEUILLET-LE MINTIER, Brigitte (2006), 'Un exemple de prohibition: la recherche sur le clonage humain', in Isabelle de Lamberterie, Étienne Vergès (dir.), Quel droit pour la recherche?. Paris: LexisNexis, pp. 119-130.

FOUCAULT, Michel (1970), The Order of Things: An Archaeology of the Human Sciences. New York: Pantheon. 
Group of Advisers on the Ethical Implications of Biotechnology to the European Commission (GAEIB), ‘Ethical Aspects of Cloning Techniques’, Opinion No. 9, 28 May 1997, http://ec.europa.eu/european_group_ethics/docs/opinion9_en.pdf.

GOOLD, Benjamin J.; Lazarus, Liona (2007), 'Introduction: Security and Human Rights’, in B. J. Goold and L. Lazarus (eds.), Security and Human Rights. Portland: Hart Publishing, pp. 1-26.

GOOLD, Benjamin J. (2007), 'Privacy, identity and security', in B. J. Goold and L. Lazarus (eds.), Security and Human Rights. Portland: Hart Publishing, pp. 45-72.

HABERLE, Peter (2003), El Estado Constitucional. México: Universidad Nacional Autónoma de México, Instituto de Investigaciones Jurídicas.

HABERMAS, Jurgen (1996), Between Facts and Norms, Contributions to a Discourse Theory of Law and Democracy. Cambridge: The MIT Press.

HABERMAS, Jurgen (1986), Law and Morality, The Tanner Lectures. Cambridge: Harvard University.

HERT, Paul de (2005), 'Biometrics: legal issues and implications', http://cybersecurity.jrc.ec.europa.eu/docs/LIBE\%20Biometrics\%20March\%2005/LegalImplications Paul de Hert.pdf.

HORNUNG, Gerrit (2007), 'The European Regulation on Biometric Passports: Legislative Procedures, Political Interactions, Legal Framework and Technical Safeguards', SCRIPT-ed, 4:3, pp. 246-262, http://www.law.ed.ac.uk/ahrc/script-ed/vol4-3/hornung.pdf.

IPTS - Institute for Prospective Technological Studies (2005), 'Biometrics at the Frontiers: Assessing the Impact on Society', Joint Research Centre, European Commission, http://ec.europa.eu/justice home/doc centre/freetravel/doc/biometrics eur21585 en.pdf.

KISS, Alexandre (2004), 'Environmental and consumer protection', in S. Peers and A. Ward (eds.), The EU Charter of Fundamental Rights. Politics, Law and Policy. Portland: Hart Publishing, pp. 247-268. 
LAZARUS, Liora (2007), 'Mapping the right to security', in B. J. Goold and L. Lazarus (eds.), Security and Human Rights. Portland: Hart Publishing, pp. 325-346.

LIBERATORE, Angela (2007), 'Balancing Security and Democracy, and the Role of Expertise: Biometrics Politics in the European Union', European Journal on Criminal Policy and Research, No. 13, pp. 109-137.

MARCHE, Régis (2008), 'Conflits de valeurs entre la recherche et la société', in Isabelle de Lamberterie, Étienne Vergès (dir.), Quel droit pour la recherche ?. Paris: LexisNexis, pp. 33-41.

MARX, Gary T. (1988), ‘La société de sécurité maximale’, Déviance et Société, Vol. 12, No. 2, pp. 147-166.

MARX, Gary T. (2008), 'Vigilância soft - o crescimento da voluntariedade obrigatória na recolha de dados pessoais. ó amigo, empresta-me uma amostra de DNA?', in C. Fróís (ed.), A Sociedade Vigilante. Lisbon: Imprensa da Ciências Sociais, pp. 87-109.

MATTHEWS, Kirstin (2007), 'Overview of World Human Cloning Policies', http://cnx.org/content/m14834/latest/.

MORIN, Edgar (2004), 'L'éthique de la complexité et le problème des valeurs au XXI ${ }^{\mathrm{e}}$ siècle', in Jerome Bind (dir.), Où Vont les Valeurs?. Paris : Éditions Unesco/Albin Michel.

Regulation No. 390/2009 of the European Parliament and of the Council of 23 April 2009 amending the Common Consular Instructions on visas for diplomatic missions and consular posts in relation to the introduction of biometrics, including provisions on the organisation of the reception and processing of visa applications.

ROBINSON, Neil, et al. (2009), Review of the European Data Protection Directive. Rand Europe.

SOARES, António Goucha (2002), A Carta dos Direitos Fundamentais da União Europeia. Coimbra: Coimbra Editora.

TSAKYRAKIS, Stavros (2008), 'Proportionality: An assault on Human Rights?', Jean Monnet Working Paper 09/08, http://centers.law.nyu.edu/jeanmonnet/papers/08/080901.pdf. 
Does the centrality of human values in the Lisbon treaty promise more than it can actually offer? Biometrics law and policy as a case study

UNESCO (1997), Universal Declaration on the Human Genome and Human Rights, Paris.

VON BODGANDY, Armin (2000), 'The European Union as a Human Rights Organization? Human Rights and the core of the European Union’, Common Market Law Review 37, pp. 1307-1338.

WYNNE, Brian, et al. (2007), Taking European Knowledge Society Seriously. Directorate-General for Research. European Commission,

http://ec.europa.eu/research/science-society/document_library/pdf_06/european-knowledge-society_en.pdf.

ZAGREBELSKY, Gustavo (2002), 'Diritto per: valori, principi o regole? (a proposito della dottrina dei principi di Ronald Dworkin'), Quaderni fiorentini per la storia del pensiero giuridico moderno, Vol. 31, pp. 865-897.

\section{Case law}

Case 377/98, Kingdom of the Netherlands v European Parliament and Council of the European Union, [2001] ECR I-07079.

Opinion of Advocate General Jacobs, delivered on 14 June 2001, Case 377/98, Kingdom of the Netherlands v European Parliament and Council of the European Union, [2001] ECR I-07079

Case C-137/05, United Kingdom of Great Britain and Northern Ireland v Council of the European Union [2007] ECR I-11593.

Opinion of Advocate General Trstenjak, delivered on 10 July 2007, Case C-137/05, United Kingdom of Great Britain and Northern Ireland v Council of the European Union [2008] ECR I- 02245. 